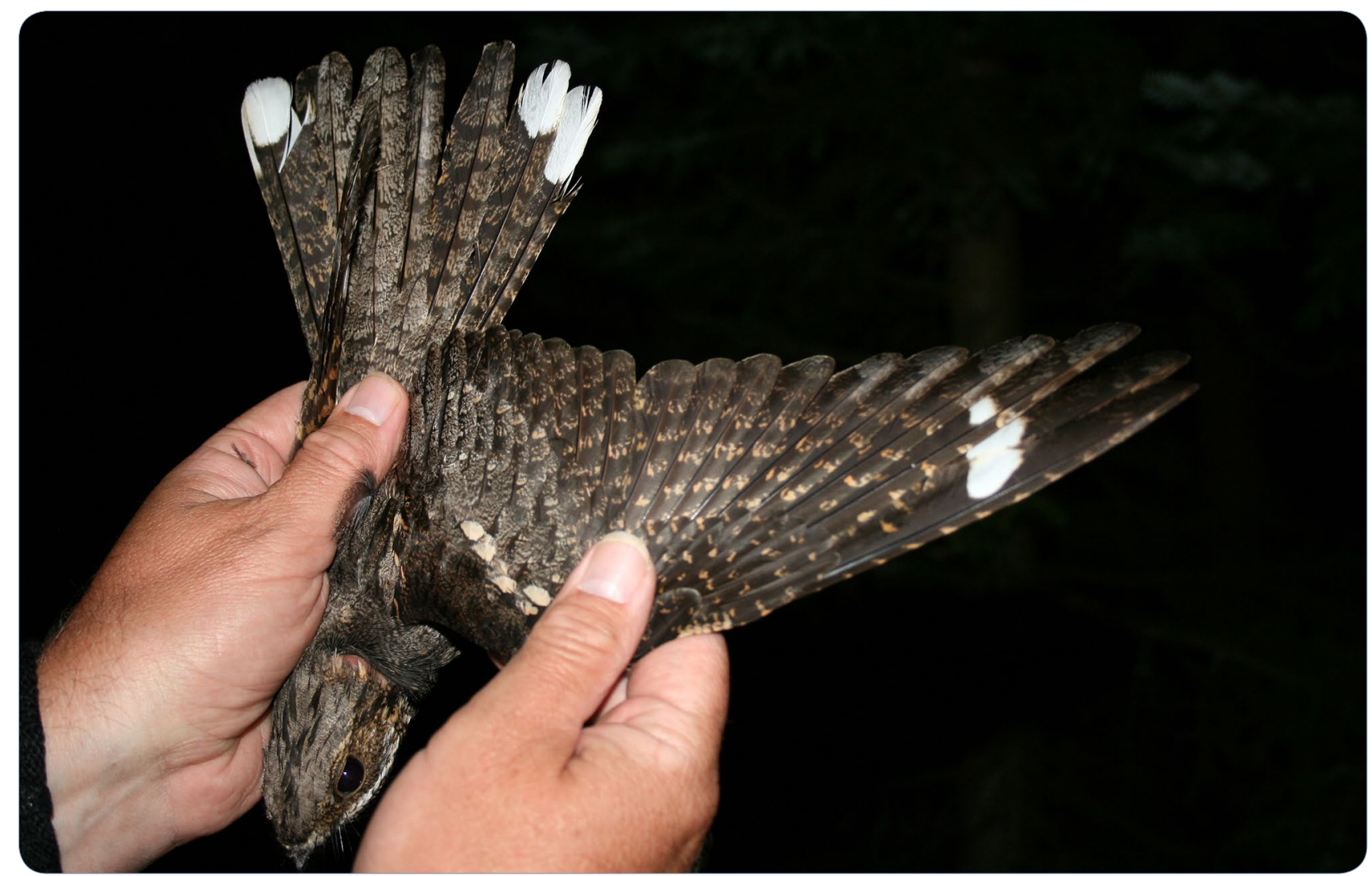

Annual spatiotemporal migration schedules in three larger insectivorous birds: European nightjar, common swift and common cuckoo

Jacobsen et al.

() BiolMed Central 


\title{
Annual spatiotemporal migration schedules in three larger insectivorous birds: European nightjar, common swift and common cuckoo
}

\author{
Lars Bo Jacobsen ${ }^{1}$, Niels Odder Jensen^, Mikkel Willemoes ${ }^{1}$, Lars Hansen^, Mark Desholm², Anthony D. Fox ${ }^{3}$, \\ Anders P. Tøttrup ${ }^{1}$ and Kasper Thorup ${ }^{1 *}$ (1)
}

\begin{abstract}
Background: Knowledge of spatiotemporal migration patterns is important for our understanding of migration ecology and ultimately conservation of migratory species. We studied the annual migration schedules of European nightjar, a large nocturnal insectivore and compared it with two other larger migratory insectivores, common swift and common cuckoo. All species breed in North Europe and winter in sub-Saharan Africa, but estimating their spatiotemporal non-breeding distributions from observations is complicated by the occurrence of similar local African species. We used geolocators to track the annual migrations of nightjars and swifts and compared these with satellite tracking of cuckoo migration.
\end{abstract}

Results: Individuals of the three species migrated to wintering grounds centered in Central Africa, except some common swifts that remained in West Africa, crossing or circumventing the Sahara along different routes in spring and fall. Overall, all species showed similar regional and seasonal use of several stopover areas during migration. Among the three species, European nightjars and common cuckoos showed the most similar spatiotemporal migration patterns. The nightjars wintered in SW Central Africa and breeding and wintering made up by far the two longest stationary periods. Swifts were generally more mobile, and some individuals progressively visited areas further east in East Africa during winter and further west in West Africa on spring migration; this species also spent less time on stopovers, but more on wintering areas. Cuckoos were intermediate in their extent of movements. The speed of nightjar spring migration was equal to that of fall migration, in contrast to the two other species where spring return to breeding areas was faster.

Conclusions: Ecological requirements are potentially useful for understanding spatiotemporal migration patterns and causes of declines in migratory species.

Keywords: Long-distance migration, Migration speed and timing, Large insectivores, European nightjar, Geolocators

\section{Background}

Basic knowledge of the ecological requirements of migratory species throughout their annual cycle and the

\footnotetext{
*Correspondence: kthorup@snm.ku.dk

$\wedge$ Deceased

${ }^{1}$ Center for Macroecology, Evolution and Climate, Natural History Museum of Denmark, University of Copenhagen, Universitetsparken 15, 2100 Copenhagen, Denmark

Full list of author information is available at the end of the article
}

evolution of species-specific migration schedules is surprisingly poor [1]. Evaluating the importance of different parts of the annual cycle is complicated by the fact that most long-distance migrants are small birds, and thus, their annual migrations to date have been difficult to study. However, using satellite telemetry, it is now possible to track birds down to the size of cuckoos Cuculus and small archival light recorders (hereafter referred to 
as geolocators) enable mapping migration of even small songbirds based on light-level geolocation [2,3].

Palearctic-African bird migrants presumably track seasonal resource availability on a continental scale [4, 5], but it is less clear what factors shape variation in speciesspecific and individual migration patterns. Large variation among species in spatiotemporal schedules is well documented, but poorly understood, with very little theoretical work developed to explain such differences. In general, seasonal species distributions have been mapped using observations and ringing [6] supplemented in some cases with estimated distributions based on niche modeling [7].

Differences in fundamental niches alone are insufficient to explain, for instance, the striking differences, in some cases, between the wintering grounds and migration routes of closely related species, such as found in Ficedula flycatchers $[8,9]$ and Luscinia nightingales [10, 11]. Such patterns could be caused by different population histories (potentially explaining why birds circumvent the Mediterranean via the eastern or the western flyway) or competitive exclusion. Detoured routes as seen in red-backed shrikes Lanius collurio breeding in Spain that migrate to East Africa via the Balkans could be constrained by colonization routes [12] but may be optimal for other reasons such as wind assistance $[13,14]$.

Several theoretical studies have dealt with the temporal component of migration schedules [15]. Annual schedules need to accommodate key elements of the annual cycle, most importantly breeding, molt and migration [16]. Optimal scheduling depends on a number of factors, with each activity influencing the timing of the others [15]. During migration, individuals are, from an optimality perspective, expected to minimize time, energy and/or predation [17]. Optimal migration theory commonly assumes that time minimization is important for migrants and this has also been reported empirically [18]. As a consequence, migrants would be expected to stopover slightly longer and undertake longer migration legs (hence making fewer stops) than expected from an energy minimization strategy where the costs of carrying extra fuel offset the gain of traveling faster. In general, smaller species are expected to migrate faster by flapping flight than larger species [19] and species with high settling costs and low fueling efficiency are expected to undertake longer stopovers.

Species-specific biology has rarely been considered explicitly when explaining migration schedules, although these are likely to be important. Our objective here is to describe the migration schedules of ecologically similar species and to discuss whether ecological similarities might lead to similarity in migration patterns. We focus on three species of larger insectivorous birds, European nightjar Caprimulgus europaeus, common cuckoo Cuculus canorus and common swift Apus apus.

European nightjars and common cuckoos are large (both have wing lengths around $0.6 \mathrm{~m}$ and weigh around 80 and $110-130 \mathrm{~g}$, respectively) insectivorous species $[20,21]$. The cuckoos feed mainly on caterpillar larvae, whereas nightjars catch low flying insects, often caught by hawking from the ground. Swifts are slightly smaller (wing $0.45 \mathrm{~m}$ and weight $44 \mathrm{~g}$ ), strictly aerial insectivores foraging exclusively on the wing [22] presumably enabling foraging during migration. In contrast to swifts, both nightjars and cuckoos forage on much larger insect species $[20,21]$. Furthermore, the common cuckoo is an obligate brood parasite [21], so their migration schedules are not constrained by parental care.

We used geolocators to map the spatiotemporal migration schedule of the European nightjars and compared it with that of common cuckoos Cuculus canorus ([23], same data set as included here) and common swifts Apus apus ([22], using other data set). Based on the tracking data, we describe similarities and differences among the three species in spatial patterns, length of sedentary stay periods, duration of fall and spring migration episodes as well as speed of migration. We then discuss whether these potentially arise due to species-specific characteristics. To compare migration patterns, we focus on migration strategies for migrants that spend the winter in the same general area. Overall, nightjars, cuckoos and swifts wintered in Central Africa, but some swifts stopped migration early and stayed in West Africa for the winter and these were excluded from comparisons. Obviously, the three species studied represent only a small subsample of the Afro-Palearctic migrants, and thus, our results cannot necessarily be generalized to other migratory species.

\section{Methods}

Using playback and mist nets, we trapped 10 male European nightjars in June and July 2010 and 14 males in June and July 2011 in Northern Jutland, Denmark $\left(57.06^{\circ} \mathrm{N}\right.$, $9.13^{\circ} \mathrm{E}$ ). Birds were ringed with a metal ring and fitted with geolocators (Mk 10_S; 1.1 g; British Antarctic Survey, BAS [24]). The light sensor was placed on a $0.8 \mathrm{~cm}$ stalk, in order to raise the sensor above the plumage. We attached the loggers as a backpack using a full-body loop harness (comparable to the wing harness in [25]) made from a 2-mm-wide braided nylon string. Females were released without geolocators because in previous years we recaptured a lower proportion of females than males. Geolocators from seven male nightjars were retrieved by July 2013 and data were available from six (2010-2011: 4; 2011-2012: 2). In three devices, logging had stopped before the bird returned to the breeding site (on 28 
March, 18 April and 7 May). An extra effort was devoted to catch birds from territories that were provided with geolocators, presumably resulting in a slightly higher recapture rate $(29 \%)$ than the rate of $20 \%$ of ringed-only male nightjars (own data).

A total of 25 common swifts were trapped during breeding at two Danish locations. At Bjødstrup, eastern Jutland $\left(56.29^{\circ} \mathrm{N}, 10.53^{\circ} \mathrm{E}\right), 10$ and 7 individuals were fitted with geolocators in 2010 and 2011, respectively, of which 6 individuals were re-trapped (2010-2011: 3; 2011-2012: 3). At Nyborg, Fyn $\left(55.30^{\circ} \mathrm{N}, 10.82^{\circ} \mathrm{E}\right), 8$ individuals were fitted with geolocators in 2010 of which 3 returned in 2011 and 1 returned in 2012. The recapture rate $(40 \%)$, was below the rate reported in a similar study (75\% [22]). This is potentially due to birds switching between local nest sites from year to year (as we have observed in previous cases but no quantitative data are available), and we could not obtain permissions to recapture birds located at nearby nest sites located in adjacent private houses. We used geolocators (Mk 20, $0.6 \mathrm{~g}$ from BAS) fitted on the birds using a body loop harness made from 1-mm braided nylon string. Birds were trapped between sunset and full darkness in mist nets close to the nesting site or in the nest box.

The Copenhagen Bird Ringing Centre with permission from the Danish Nature Agency approved capturing and tagging of nightjars and swifts.

\section{Location estimation}

Data for nightjars were downloaded and analyzed using the BASTrak software suite [26]. We defined sunrises and sunsets using the threshold method with a sun angle estimated for each individual. There was an unusually high level of noise in the light measurements on many days, possibly caused by shading from either the vegetation that the birds hide in during day or from the feathers on the back of the birds. To account for this noise, we only used data from days with little noise (measured as standard deviation in the light measurements between sunrise and sunset). To decide the acceptable level of noise, we looked for the level under which the estimated latitudes were stable during breeding (Additional file 1: Fig. S1). Because we filtered out the days with most noise, we only needed to discard all latitudes within two weeks on each side of the equinoxes. The remaining data were calibrated to the breeding latitude during their breeding site attendance and the derived sun angles $\left(-2.2^{\circ}\right.$ to $-5.0^{\circ}$ ) were used to estimate positions (Additional file 2). We compared this to using Hill-Ekström calibration [27] during the longest non-breeding stopover, but presumably because of the amount of noise in the data this was only possible for two birds. Hill-Ekström calibration requires that there is a specific sun elevation angle that corresponds to a local minimum in latitude variation during a stopover. We tested angles between $0^{\circ}$ and $-8^{\circ}$ and found no minimum in four birds; in the two birds where we found a minimum in latitude variation, the estimated sun elevation angle was within $0.5^{\circ}$ of the one obtained using breeding latitude calibration.

The cuckoo data are from eight published satellite tracked birds with completed fall migration in 2010 of four males and two females, and three males and one female in spring 2011 ([23]; Fig. 2; Additional file 2). The common swift data from light-level-based geolocators were analyzed using a threshold of 2 , a sun angle of $-5^{\circ}$ and excluding three weeks around the equinox. To calibrate the sun elevation angle we used Hill-Ekström calibration [27] during the longest non-breeding stopover. All resulting sun elevation angles were between $-4.5^{\circ}$ and $-5.5^{\circ}$, and we used $-5^{\circ}$ for all individuals (Additional file 2).

\section{Breeding, stopover and wintering periods: location, timing and distances}

We used departure in one year and return in the following year to calculate duration of breeding in all three species.

For geolocator data (nightjars and swifts), we defined a stopover as when the birds interrupted their migration for more than 5 days and calculated an estimated stopover position by averaging the longitudes and latitudes during this period. We estimated stopover and movement periods based on changes in latitude and longitude except during equinox, when only longitude was considered. Dictated by the uncertainty of light-level data [27], we required consecutive stopovers to be separated by more than four degrees either latitude or longitude; otherwise, the two locations were considered part of the same stopover and the location was acquired as the average throughout both stops. Departure and arrival dates were taken as the last and first, respectively, days that were within two degrees longitude of the average location estimate (Additional file 3).

In the nightjar, some of the fall and spring stopovers occurred during equinox, making latitude estimation impossible. To estimate these stopovers for illustration (Fig. 1), we calculated theoretically realistic latitudinal spans based on travel speeds. These were calculated using the preceding or following stopover (if the preceding was not available), travel speeds of $200-500 \mathrm{~km} /$ day $[3,23]$ and the longitude estimated from the light data during the stopover. We calculated the overall migrating distance as the minimum distance between breeding site, stopover sites and winter area. For this calculation, we also included estimated stopovers during equinox which provided data on individual movement, despite being disregarded because of their positional uncertainty. 


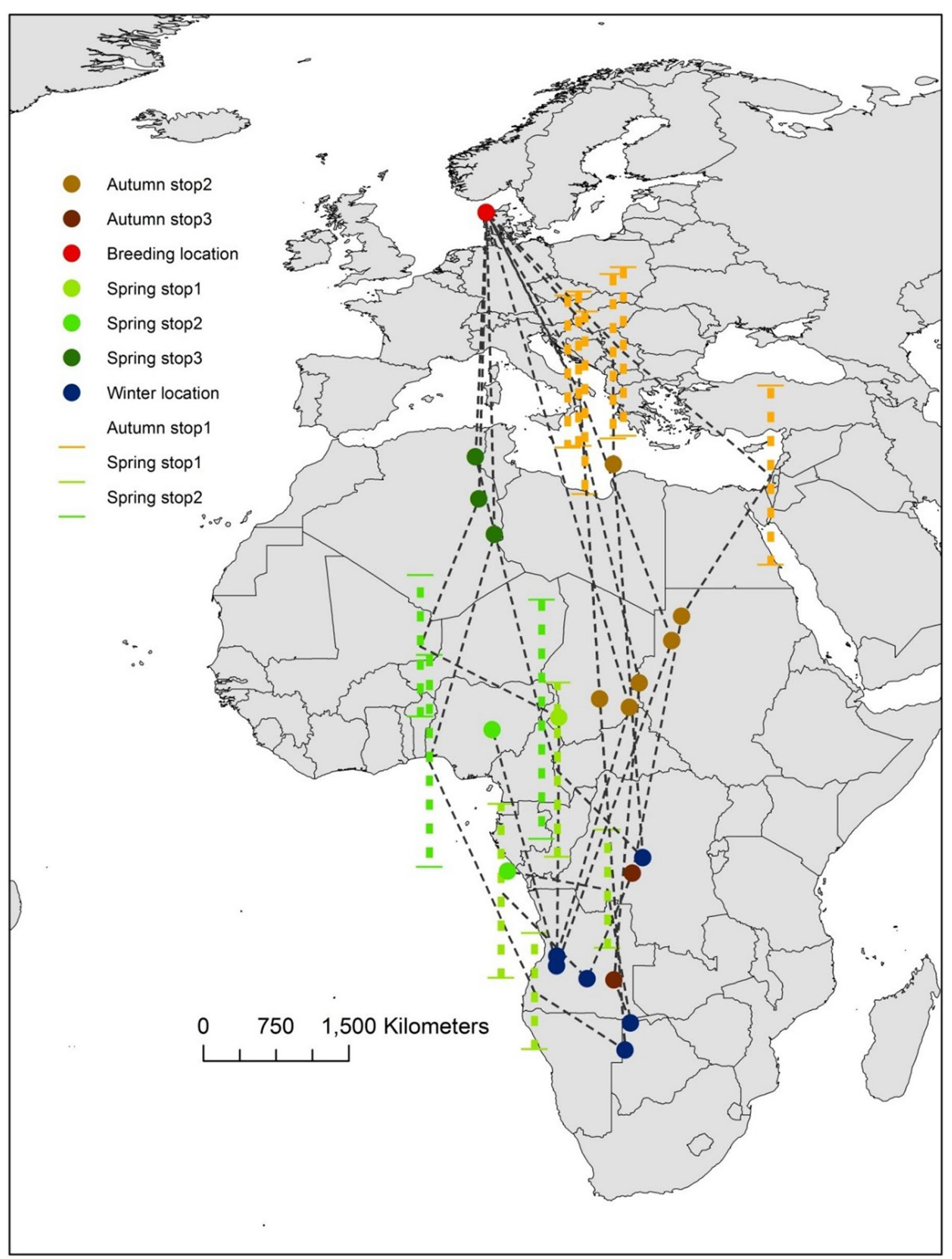

Fig. 1 Main stopovers used by six European nightjars during migration. Colored circles are light-level-based geolocation stopover positions estimated using breeding site calibration. Positions are means of high-quality latitude and longitude estimates (see "Methods" section) during the full length of the stopovers. For stopovers latitudes during Equinox, intervals assuming realistic migration speeds (dotted lines correspond to speeds of 200-500 km/day; squares correspond to $350 \mathrm{~km} /$ day) rather than positions are indicated 
Migration speed was calculated as migration segment distance divided by duration of the migration segment. All durations of segments include days stopping over. Some might only be a few days (shorter than what we consider a stopover), making some migration speeds close to travel speeds.

For satellite tracking data (cuckoos), we defined stopovers, dates and distances overall similarly. However, the higher accuracy of the satellite tracking data theoretically allows for separation of small-scale changes between sites. However, we grouped cuckoo stopovers in specific geographical regions at a spatial scale similar to that which we obtained for the other two species. Individual stopover locations were estimated as averages within these regions as described in [22]. Because of non-daily transmissions, departure and arrival dates are rarely identifiable and we used last and first, respectively, days within the region/site in question (Additional file 3).

Geolocators in most cases allow for accurate determination of stopover timing to within 1 day. Because of the $10 \mathrm{~h}$ on $48 \mathrm{~h}$ off duty cycle of the satellite transmitters, estimation of departures from stopovers was less accurate for satellite data and transmissions were occasionally missed, resulting in even less accurate estimates. We based stopover duration only on known locations resulting in potential underestimation of stopover duration (and overestimation of travel time). Missing transmissions only occurred relatively frequently in Europe during fall, potentially leading to underestimates of stopover duration of cuckoos here. However, we found that cuckoos staged for longer periods than the other species in this region anyway. Therefore, we conclude that our comparisons of stopover duration are likely conservative.

\section{Comparison of European nightjar with common swift and common cuckoo}

We compare the migration routes and the timing of the nightjars to those of common cuckoos and common swifts. The study of migration in all three species is challenging given their relatively small size, long-distance migration and difficult study conditions in the wintering area (ranging from being nocturnal to highly aerial often in highly remote areas). To make the data comparable among species, we included only adult birds (but were not able to separate sexes in analyses). Thus, our sample sizes are necessarily small. The different species were mostly tracked in the same year but some nightjars and swifts were from a year later than the cuckoos. As birds' schedules could vary as a response to the variable conditions among years, comparing schedules from the same year would have been preferable. At least at the regional scale that we are considering, we do not expect any major differences among years. Similar consistency in stopover use has also been reported in other longdistance migrants, for example red-backed shrikes [10] although their timing appears more flexible.

The three species showed overall similarities in the routes and timing taken: all undertook stopovers in the Sahel after leaving Europe, subsequently spending the major part of the non-breeding season, i.e., wintering, in Central Africa and at stopover sites in West Africa before returning to the breeding sites. We therefore compared the timing of departure and arrival in these four places: breeding, Sahel $\left(8-20^{\circ} \mathrm{N}\right.$ ), wintering (south of $5^{\circ} \mathrm{N}$ and east of $10^{\circ} \mathrm{E}$ ) (for swifts this could include trips to eastern Africa) and West Africa (west of $10^{\circ} \mathrm{E}$ and $0-20^{\circ} \mathrm{N}$ ) in spring. We also compared durations of stopovers as well as migration speed. Roaming behavior during the non-breeding season was quantified as the number of stationary periods as well as the distance traveled among stationary sites during winter. Because we aim to describe differences in spatiotemporal migration patterns in species with otherwise similar constraints, we focused our analyses of the wintering period to birds wintering in the same general area, thus using only the seven swifts traveling to Central Africa (three remained in West Africa all winter). Clearly, the short-stopping swifts saved time and potentially energy by using a shorter-distance migration strategy that potentially influences their ability to fatten up before travel and speed of migration depending on local seasonal conditions.

We compare the three species fitting separate ANOVAs for each of the parameters above as a function of species. Because of the large numbers of comparisons, Bonferroni-corrected significance levels are also indicated. Overall, results should be interpreted with caution due to generally low sample sizes. Because of varying sample sizes, tests were not directly comparable and in general, we only present comparisons from significant tests. All models were fitted using general linear model (GLM) in R 3.1.0 [28].

\section{Results \\ Spatial patterns}

The six tracked nightjars performed a clockwise loop migration from breeding grounds in Denmark to winter grounds in southwest Central Africa traveling a mean total distance of $16,636 \pm 1514 \mathrm{~km}$ (mean \pm SD; range $13,993-18,200 \mathrm{~km}$ ) with no significant difference between fall and spring distances (Matched pair test, $p=0.34, n=6$ ) (Fig. 1; Table 1). The nightjars stopped over two or three times in fall and three times in spring (Fig. 1). The main wintering area was in Democratic Republic of Congo, Angola and northern Namibia/ Botswana.

Among the 10 tracked common swifts, most individuals $(n=8)$ also migrated to the Sahel before continuing 
Table 1 Mean, standard deviation (SD) and number of individuals [ $n$ ] in each analysis of timing, duration, distance and speed for different legs of the migration for each of the three different species

\begin{tabular}{|c|c|c|c|c|c|c|c|}
\hline Parameter & Nightjar (SD) [n] & Cuckoo (SD) $[n]$ & Swift (SD) $[n]$ & $P$ model & PNi_Cu & PNi_Sw & PCu_Sw \\
\hline \multicolumn{8}{|c|}{ Timing (day of year one) } \\
\hline Dep. breeding & $250(7)[6]$ & $191(13)[8]$ & $222(8)[9]$ & $\underline{0.000}$ & $\underline{0.000}$ & $\underline{0.000}$ & $\underline{0.000}$ \\
\hline Arr. Sahel & $280(5)[6]$ & $263(15)[6]$ & $244(11)[8]$ & $\underline{0.000}$ & 0.018 & $\underline{0.000}$ & 0.006 \\
\hline Dep. Sahel & $294(3)[6]$ & $301(12)[6]$ & $280(15)[8]$ & 0.014 & 0.371 & 0.040 & 0.005 \\
\hline Arr. C. Africa & $301(3)[6]$ & $307(14)[6]$ & $288(16)[7]$ & 0.044 & 0.451 & 0.080 & 0.017 \\
\hline Dep. C. Africa & 449 (15) [6] & $450(21)[5]$ & $471(11)[7]$ & 0.036 & 0.897 & 0.021 & 0.036 \\
\hline Arr. W. Africa & $455(16)[6]$ & $458(18)[5]$ & 481 (11) [7] & 0.015 & 0.753 & 0.008 & 0.021 \\
\hline Dep. W. Africa & $475(10)[4]$ & $487(12)[4]$ & $495(4)[10]$ & $\underline{0.001}$ & 0.035 & $\underline{0.000}$ & 0.083 \\
\hline Arr. breeding & 493 (12) [3] & 505 (12) [3] & $506(6)[10]$ & 0.104 & 0.120 & 0.038 & 0.812 \\
\hline \multicolumn{8}{|l|}{ Duration (days) } \\
\hline Breeding Sahel & $30(10)[6]$ & 57 (15) [3] & 27 (10) [7] & 0.004 & 0.004 & 0.649 & 0.002 \\
\hline Sahel-C. Africa & $7(2)[6]$ & $6(4)[5]$ & $8(5)[6]$ & 0.875 & 0.755 & 0.837 & 0.612 \\
\hline Fall & $52(9)[6]$ & $113(31)[5]$ & $69(21)[8]$ & $\underline{0.001}$ & $\underline{0.000}$ & 0.161 & 0.002 \\
\hline Fall stops & $31(8)[6]$ & $88(30)[5]$ & $43(20)[8]$ & $\underline{0.001}$ & $\underline{0.000}$ & 0.323 & $\underline{0.001}$ \\
\hline C. Africa-W. Africa & $6(2)[6]$ & $8(4)[5]$ & $9(6)[7]$ & 0.463 & 0.549 & 0.222 & 0.573 \\
\hline W. Africa breeding & $23(6)[3]$ & $18(2)[3]$ & $11(5)[10]$ & 0.005 & 0.270 & 0.003 & 0.038 \\
\hline Spring & 55 (13) [3] & 65 (7) [3] & $34(9)[7]$ & $\underline{0.001}$ & 0.206 & 0.008 & $\underline{0.001}$ \\
\hline Spring stops & $40(11)[3]$ & $48(7)[3]$ & $20(8)[6]$ & 0.002 & 0.255 & 0.009 & $\underline{0.001}$ \\
\hline Breeding & $127(15)[3]$ & 49 (3) [3] & $82(11)[9]$ & $\underline{0.000}$ & $\underline{0.000}$ & $\underline{0.000}$ & $\underline{0.001}$ \\
\hline C. Africa & $148(15)[6]$ & $139(23)[5]$ & $183(13)[7]$ & $\underline{0.001}$ & 0.422 & 0.002 & $\underline{0.000}$ \\
\hline Migration & $100(16)[3]$ & $185(25)[3]$ & 105 (19) [5] & $\underline{0.001}$ & $\underline{0.001}$ & 0.758 & $\underline{0.001}$ \\
\hline Non-migration & $265(16)[3]$ & $180(25)[3]$ & $260(19)[5]$ & $\underline{0.001}$ & $\underline{0.001}$ & 0.758 & $\underline{0.001}$ \\
\hline \multicolumn{8}{|l|}{ Distance (km) } \\
\hline Breeding Sahel & 4656 (925) [6] & $5048(89)[6]$ & $6693(675)[5]$ & $\underline{0.000}$ & 0.323 & $\underline{0.000}$ & $\underline{0.001}$ \\
\hline Sahel-C. Africa & 3560 (479) [6] & $1822(503)[6]$ & 2310 (516) [5] & $\underline{0.000}$ & $\underline{0.000}$ & $\underline{0.001}$ & 0.128 \\
\hline Fall & 8215 (760) [6] & $6870(528)[6]$ & 7954 (1379) [10] & 0.085 & 0.041 & 0.639 & 0.063 \\
\hline C. Africa-W. Africa & 1658 (906) [5] & $1986(572)[5]$ & 2912 (963) [7] & 0.056 & 0.553 & 0.025 & 0.084 \\
\hline W. Africa breeding & $5555(815)[5]$ & 5691 (146) [3] & 5906 (291) [10] & 0.413 & 0.705 & 0.203 & 0.507 \\
\hline Spring & 7180 (1015) [6] & 7898 (376) [3] & 7944 (1729) [10] & 0.572 & 0.485 & 0.313 & 0.961 \\
\hline \multicolumn{8}{|l|}{ Speed (km/day) } \\
\hline Breeding Sahel & $178(92)[6]$ & $92(24)[3]$ & $316(76)[4]$ & 0.010 & 0.153 & 0.021 & 0.004 \\
\hline Sahel-C. Africa & $577(258)[6]$ & $371(120)[5]$ & $553(370)[4]$ & 0.406 & 0.212 & 0.885 & 0.316 \\
\hline Fall & $162(30)[6]$ & $65(17)[5]$ & $161(103)[9]$ & 0.065 & 0.044 & 0.981 & 0.032 \\
\hline C. Africa-W. Africa & $281(177)[5]$ & $363(328)[3]$ & 369 (163) [7] & 0.750 & 0.596 & 0.477 & 0.964 \\
\hline W. Africa breeding & $236(63)[3]$ & $313(29)[3]$ & $666(305)$ [10] & 0.033 & 0.720 & 0.024 & 0.055 \\
\hline Spring & $131(52)[3]$ & $122(17)[3]$ & 331 (131) [10] & 0.012 & 0.924 & 0.017 & 0.014 \\
\hline
\end{tabular}

$P$ model is the $p$ value of a general linear model with species as predictor, and the other three $p$ values are testing pairwise differences between species (Ni nightjar, $C u$ cuckoo, Sw swift). $p$ values $<0.05$ are in italics. $p$ values $<0.0016$ (applying a Bonferroni correction) are in italic underline

to Central Africa, but the swifts migrated via the Iberian Peninsula, followed the northwest African coast and then turned east toward the central Sahel (Fig. 2). Three swifts spent the entire winter in West Africa, whereas the remaining seven wintered in Central Africa. While in Central Africa, the birds used on average four different locations $( \pm 0.9 \mathrm{SD})$ and four of the birds even visited East and Southeast Africa. In contrast, the cuckoos and nightjars only used two different locations ( \pm 0.5 and \pm 1 , respectively) in the Central African wintering range. The eight tracked common cuckoos (Fig. 2) showed a clockwise loop migration to the eastern Sahel, Central Africa, West Africa and back to Europe through Tunisia. In spring, all three species travelled to West Africa before going back to Europe, but swifts travelled further west than the other two, and cuckoos further west than nightjars (mean longitude swift: $-9.3^{\circ} \pm 1.7^{\circ}, n=10$; cuckoo: $-2.0^{\circ} \pm 5.3^{\circ}, n=5$; nightjar: $7.6^{\circ} \pm 4.8^{\circ}, n=5$; ANOVA: $F_{2,17}=8.6, p=0.002$ ). 


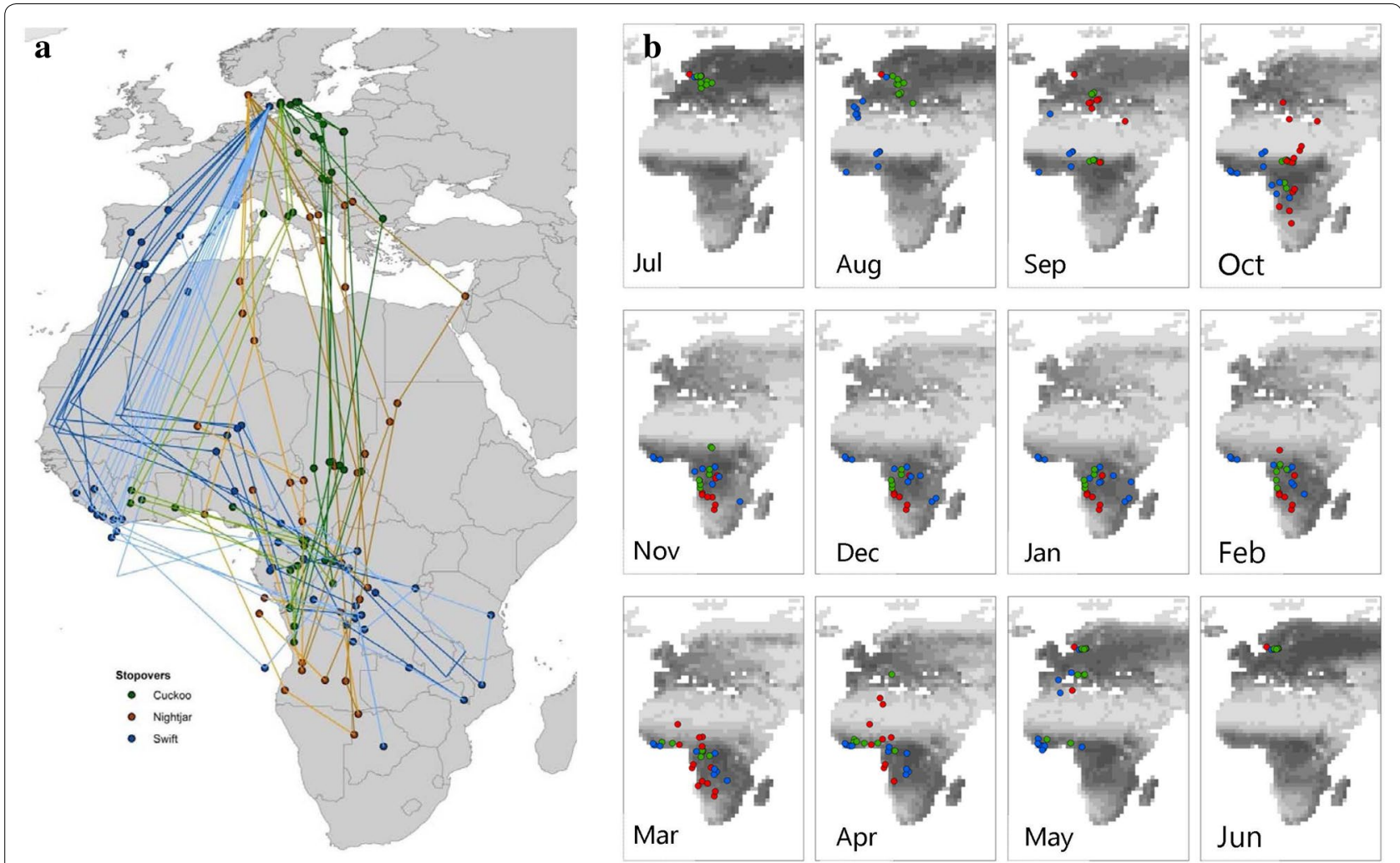

Fig. 2 Comparison of migration routes between European nightjars, common cuckoos and common swifts. Circles indicate stopover areas used for at least 5 days. Species are shown in different colors (green $=$ cuckoo, brown $=$ nightjar, blue $=$ swift). Nightjars and swifts were tracked with lightlevel-based geolocators with considerable uncertainty, especially for latitudes; cuckoos were tracked with high accuracy satellite transmitters [22]. Several of the nightjar locations included here (for illustration purposes) are extrapolated from known longitude and latitude based on an estimated flying speed of 350 km/day (see Fig. 1 for full latitude span). a Complete annual migration. Lines connect stopover locations and do not necessarily reflect route taken (for swift in fall, the easternmost point of the Sahara crossing is included for illustration of the Zugknick here) with darker shading indicating fall and lighter spring migration, $\mathbf{b}$ locations month by month. Background layer is vegetation greenness in each $2^{\circ}$ latitude $\times 2^{\circ}$ longitude cells averaged for each period 2000-2010 derived from on NOAA-16 Normalized Difference Vegetation Index (NDVI), AVHRR NDVI3 g.V0 [29]

Overall, the spatial migration pattern of cuckoos was very similar to that of the nightjars, both showing clockwise loop migration, differing from that of swifts (Fig. 2).

\section{Sedentary stays}

The timing of nightjars (Additional file 1: Tables S1, S2) was roughly similar to the timing of both swifts and cuckoos, although most similar to that of cuckoos (Fig. 3; Table 1). Nightjar southbound migration from the breeding grounds started in September (mean date 6 September, range 30 August-17 September) with arrival to the wintering area in October/November (mean date 28 October, range 25 October-3 November). They stayed in Central Africa on average $148 \pm 15$ days (range 135-174, $n=6$; Fig. 1) and northbound migration started in March/April (mean 25 March, range 13 March-17 April). The three species differed in the number of days they spent in Central Africa $(p<0.001$; Table 1$)$, where cuckoos (139 \pm 23 days, $n=5)$ spent similar time to nightjars, but swifts stayed for substantially longer (183 \pm 13 days, $n=7$ ). Furthermore, swifts traveled further $(4180 \pm 2059 \mathrm{~km}, n=7)$ within the winter region than nightjars and cuckoos $(1280 \pm 1210 \mathrm{~km}$, $n=6 ; 1086 \pm 667 \mathrm{~km}, n=5$, respectively). The nightjars spent on average $127 \pm 15$ days on the breeding site (using departure and arrivals from different years, $n=3$ ). Time spent on the breeding site differed among species $(p<0.001$; Table 1$)$, with swifts $(82 \pm 11$ days, $n=9)$ spending less time than nightjars; cuckoos ( $49 \pm 3$ days, $n=3$ ) spent least time of all species.

Departure from the breeding grounds and arrival to the Sahel differed among the three species $(p<0.001)$. Cuckoos were the first to depart breeding grounds (11 Jul \pm 13 days, $n=8)$ followed by swifts (10 Aug \pm 8 days, $n=9$ ) then nightjars (6 Sep \pm 7 days, $n=6$ ). Swifts arrived to the Sahel first ( 1 Sep \pm 11 days, $n=8$ ) followed by cuckoos (20 Sep \pm 15 days, $n=6$ ) and nightjars (7 Oct \pm 5 days, $n=6$ ). Departure from West Africa 


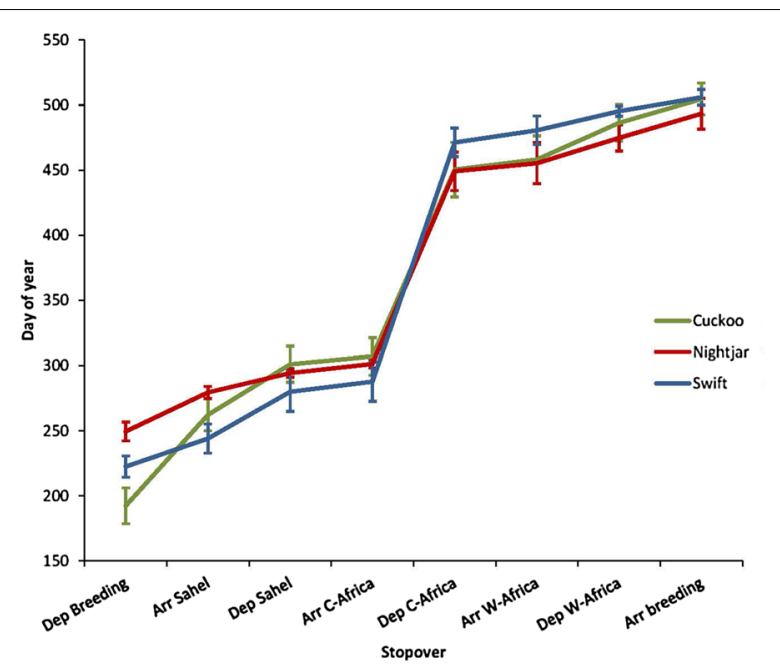

Fig. 3 Comparison of timing of departures and arrivals from different geographical regions shared between the three species. Error bars indicate standard deviations. For swifts, timing analyses are based only on individuals reaching Central Africa. Significance tests for each state are given in Table 1

differed ( $p=0.001)$ with nightjars (19 Apr \pm 10 days, $n=4$ ) departing earlier than cuckoos (30 Apr \pm 12 days, $n=4)$ and swifts (10 May \pm 4 days, $n=10$ ).

\section{Duration and speed of fall and spring migration}

The nightjars spent $31 \pm 8$ days (range 21-44 days, $n=6$ ) in total on stopover sites in fall and $40 \pm 11$ (range $30-51$ days, $n=3$ ) in spring. Number of stopover days in fall differed between the three species $(p=0.001$; Fig. 3 ; Table 1), where nightjars spent substantially less time on fall stopovers than did cuckoos ( $88 \pm 30$ days, range 53-115 days, $n=5$ ) but a similar amount of time to swifts (43 \pm 20 days, range $10-67$ days, $n=8$ ). Spring stopover duration also differed between species $(p=0.002)$ with nightjars being comparable to cuckoos (48 \pm 7 days, range 41-55 days, $n=3$ ), and both nightjars and cuckoos spent substantially more time than swifts (20 \pm 8 days, range $7-28$ days, $n=6$ ). The pattern was the same for total duration of fall and spring migration. Nightjars spent a similar (ANOVA: $F_{1,7}=0.19, p=0.67$ ) amount of time on spring ( $55 \pm 13$ days, range $45-70$ days, $n=3$ ) and fall migration (52 \pm 9 days, range $41-65$ days, $n=6$ ), whereas in both cuckoos (spring: $65 \pm 7$ days, range 61-73 days, $n=3$; fall: $113 \pm 31$ days, range $67-137$ days, $n=5$ ) and swifts (spring: $34 \pm 9$ days, range $19-47$ days, $n=7$; fall: $69 \pm 21$ days, range 32-94 days, $n=8$ ) fall migration is lasting significantly longer than spring migration (cuckoo: $F_{1,6}=6.6, p=0.04$; swift: $F_{1,13}=16.8, p=0.001$ ).

The mean total migration speed of nightjars (including stopover sites) in fall was $162 \pm 30 \mathrm{~km} /$ day (range
$126-214, n=6)$ and in spring $131 \pm 52 \mathrm{~km} /$ day (84-186, $n=3$ ). Fall migration speed was lowest in cuckoos but did not differ significantly between the three species. Spring migration speed did, however $(p=0.012$; Table 1$)$, with swifts $(331 \pm 131 \mathrm{~km} /$ day, $n=10)$ migrating faster than both cuckoos (122 $\pm 17 \mathrm{~km} /$ day, $n=3)$ and nightjars.

\section{Discussion}

Overall, the three species showed similar migration patterns on a regional and monthly scale, in particular compared to migration patterns reported for other species [30]. Although the tracked nightjars bred in a relatively restricted area in Denmark (within $65 \mathrm{~km}$ ), they dispersed over a much larger area in Africa and spent the winter outside the former known winter areas in Africa which do not include the central parts of the continent $[20,31]$ although three European nightjars from England and several from Sweden spent the winter in the same area as the birds from Denmark [32, 33]. Our tracks of swifts were similar to those already published from other North European populations [22].

The similarity in migration patterns suggests that for insectivorous birds of such body mass, the beneficial exploitation of the continent-wide seasonal changes in food supply leaves limited room for spatiotemporal flexibility. We found the migration pattern of European nightjars to be more similar to that of common cuckoos than that of common swifts both with regard to route and with regard to timing though common cuckoos departed breeding grounds earlier. Potentially, this could be related to similarity in ecological niche, such as insect prey size. The main difference between cuckoos and nightjars was that nightjars spent more time on the breeding grounds, because cuckoos departed breeding areas earlier possibly because they provide no parental care. As a result, there were differences in timing before, after and at the breeding site.

The swifts differ from the other two species in showing large spatial variation among individuals, with some individuals wintering in West Africa, while others wintered in Central Africa. Seven of ten common swifts covered large distances spending their "sedentary" wintering period roaming over large areas using more sites than the other species which could result from the fact that swifts forage on large numbers of small insect prey, often at high altitudes and quickly traveling large distances in response to food availability. These swifts differed temporally from the other species by spending more time in Central Africa, with a shorter stopover in West Africa, which resulted in a faster overall spring migration in these individuals (spring migration from West Africa was equally fast among the swifts that wintered in there). However, fall migration speeds were similar in the three species. 
In addition to resource needs, many other factors could be causing variation in annual migration schedules. For example, because avian annual cycles are evolved to minimize the overlap of energetically demanding events, birds must fit molt and breeding into the annual schedule at other times than during migration $[34,35]$. As the resource needs also dictate timing of molt, we assume that general migration patterns are similarly affected by periods of resource needs and expenditure.

The fact that nightjars both forage and travel at night theoretically restricts their migration speeds compared to the other species that can forage by day and travel at night (as well as by day). However, we did not find nightjar migration speeds to be generally slower or faster. In most avian species studied so far, spring migration occurs faster than fall migration, possibly because of constraints in the arrival time at the breeding area [36]. Norevik et al. [33] reported faster fall than spring migration in European nightjars. We found a similar, but non-significant difference, which contrasted the pattern in swifts and cuckoos, where spring migration is faster than fall migration [22, 23]. Compared to the other two species, the nightjar departed the breeding site substantially later yet arrived in Central Africa at the same time. Nightjars were the earliest to arrive on the breeding grounds.

The migration of the European nightjars followed different routes in fall and spring, with a more westerly spring migration trajectory. Taking a westerly route in spring may be advantageous because of stable tailwind patterns in West Sahara [37]. Additionally, they can benefit from foraging in areas where food becomes available, following the fall seasonal patterns of rain along these routes toward the winter areas [14]. Both swifts and cuckoos also traveled to West Africa before heading north, suggesting that ecological conditions favor this detour. The three species differed substantially, however, in the location of their stopover longitude.

Widespread declines have been reported recently in sub-Saharan migrant species but the causes are to a large degree unknown [38-41]. Migrant species are likely vulnerable to habitat loss because they depend on the condition of networks of sites that may be separated by thousands of kilometers [42]. As migratory animals show declines around the world [43] there is a growing need to understand potential reliance of migrants on staging regions or areas and for conservation initiatives to protect such networks [42]. An essential starting point is to understand the spatiotemporal migration patterns within and across migratory species. The comparative long duration of stay on the breeding and wintering grounds obviously direct conservation research toward these two periods and areas, but short stops at critical staging areas may also be just as crucial.

\section{Conclusions}

The spatial migration pattern of the European nightjar was more similar to that of the common cuckoo than that of the common swift. Our study illustrates the potential for investigating determinants of migratory schedules using a comparative approach.

\section{Additional files}

Additional file 1. Supplementary information on European nightjars. Data on individual birds (Table S1), stopover duration (Table S2) and definition of high-quality positions (Fig. S1).

Additional file 2. Location estimates for individual European nightjars, common swifts and common cuckoos included in the study.

Additional file 3. Estimated stopovers and timing of European nightjars, common swifts and common cuckoos.

\section{Authors' contributions}

LBJ, NOJ, LH, MD, ADF, APT, KT carried out field work on nightjars and swifts. LBJ, NOJ, MW, APT, KT analyzed the data. LBJ, NOJ, MW, APT, KT drafted the manuscript. LBJ, MW, MD, ADF, APT and KT contributed to the final manuscript. LBJ, MW, MD, ADF, APT, KT read and approved the final manuscript.

\section{Author details}

${ }^{1}$ Center for Macroecology, Evolution and Climate, Natural History Museum of Denmark, University of Copenhagen, Universitetsparken 15, 2100 Copenhagen, Denmark. ${ }^{2}$ BirdLife Denmark, Vesterbrogade 140, 1620 Copenhagen V, Denmark. ${ }^{3}$ Department of Bioscience, Aarhus University, Kalø, Grenåvej 14, 8410 Rønde, Denmark.

\section{Acknowledgements}

We thank Roine Strandberg, Raymond H.G. Klaassen and Thomas Alerstam for permission to use the Swedish cuckoo data.

\section{Competing interests}

The authors declare that they have no competing interests.

\section{Availability of data and material}

The data set(s) supporting the conclusions of this article is(are) included within the article (and its additional file(s)).

\section{Ethics approval}

This study was carried out in strict accordance with guidelines to the use of wild birds in research of the Ornithological Council [44]. Animal work on European nightjars and common swifts was approved by the Copenhagen Bird Ringing Centre (J.Nr. SN 302-009) under permission from the Danish Forest and Nature Agency.

\section{Funding}

KT thanks the Danish Council for Independent Research for support to the MATCH Project (1323-00048B). KT, MW, APT thank the Danish National Research Foundation for support to the Center for Macroecology, Evolution and Climate (DNRF96)

Received: 2 September 2016 Accepted: 5 January 2017

Published online: 08 February 2017

References

1. Bowlin MS, Bisson IA, Shamoun-Baranes J, Reichard JD, Sapir N, Marra PP, Kunz TH, Wilcove DS, Hedenström A, Guglielmo CG, Åkesson S, Ramenofsky M, Wikelski M. Grand challenges in migration biology. Integr Comp Biol. 2010;50:261-79. doi:10.1093/icb/icq013. 
2. Stutchbury BJM, Tarof SA, Done T, Gow E, Kramer PM, Tautin J, Fox JW, Afanasyev V. Tracking longdistance songbird migration by using geolocators. Science. 2009;323:896.

3. Tøttrup AP, Klaassen RHG, Strandberg R, Thorup K, Kristensen MW, Jørgensen PS, Fox J, Afanasyev V, Rahbek C, Alerstam T. The annual cycle of a trans-equatorial Eurasian-African passerine migrant: different spatio-temporal strategies for autumn and spring migration. Proc R Soc B. 2012;279:1008-16. doi:10.1098/rspb.2011.1323.

4. Moreau RE. Palaearctic-African bird migration systems. London: Academic Press; 1972

5. Thorup K, Tøttrup AP, Willemoes M, Klaassen RHG, Strandberg R, Lomas Vega M, Dasari HP, Araújo MB, Wikelski M, Rahbek C. Resource tracking within and across continents in long-distance bird migrants. Sci Adv. 2017;3:e1601360

6. Fry $\mathrm{CH}$, Keith S, Urban E. The birds of Africa, vol. 1-8. Princeton: Princeton Press; 1982-2004

7. Wisz MS, Walther BA, Rahbek C. Using potential distributions to explore determinants of Western Palaearctic migratory songbird species richness in sub-Saharan Africa. J Biogeogr. 2007;34:828-41.

8. Dowsett RJ. The separate African winter quarters of Pied Flycatcher Ficedula hypoleuca and Collared Flycatcher F. albicollis. Bull ABC. 2010:17:79-81.

9. Ouwehand J, Ahola MP, Ausems ANMA, Bridge ES, Burgess M, Hahn S, Hewson CM, Klaassen RHG, Laaksonen T, Lampe HM, Velmala W, Both C. Light-level geolocators reveal migratory connectivity in European populations of pied flycatchers Ficedula hypoleuca. J Avian Biol. 2016;47:69-83.

10. Tøttrup AP, Klaassen RHG, Kristensen MW, Strandberg R, Vardanis $Y$, Lindström Å, Rahbek C, Alerstam T, Thorup K. Drought in Africa caused delayed arrival of European songbirds. Science. 2012;338:1307.

11. Hahn S, Amrhein V, Zehtindjiev P, Liechti F. Strong migratory connectivity and seasonally shifting isotopic niches in geographically separated populations of a long-distance migrating songbird. Oecologia. 2013:173:1217-25.

12. Irwin $\mathrm{DE}$, Irwin JH. Siberian migratory birds: the role of seasonal migration in speciation. In: Marra PP, Greenberg R, editors. Birds of two worlds: the ecology and evolution of bird migration. Baltimore, MD: Johns Hopkins University Press; 2003. p. 27-40.

13. Alerstam T. Detours in bird migration. J Theor Biol. 2001;209:319-31. doi:10.1006/jtbi.2001.2266.

14. Tøttrup AP, Pedersen L, Onrubia A, Thorup K. Migration of red-backed shrikes from the Iberian Peninsula: optimal or sub-optimal detour? J Avian Biol. 2017;48. doi:10.1111/jav.01352.

15. McNamara JM, Houston Al. Optimal annual routines: behaviour in the context of physiology and ecology. Philos Trans R Soc B. 2008;363:301-19.

16. Barta Z, McNamara JM, Houston Al, Weber TP, Hedenström A, Feró O. Optimal moult strategies in migratory birds. Proc R Soc B. 2008;363:211-29.

17. Alerstam T, Lindström Å. Optimal bird migration: the relative importance of time, energy and safety. In: Gwinner E, editor. Bird migration: the physiology and ecophysiology. Berlin: Springer; 1990. p. 331-51.

18. Dänhardt J, Lindström Å. Optimal departure decisions of songbirds from an experimental stopover site and the significance of weather. Anim Behav. 2001:62:235-43. doi:10.1006/anbe.2001.1749.

19. Hedenström A, Alerstam T. How fast can birds migrate? J Avian Biol. 1998:29:424-32.

20. Holyoak DT. Nightjars and their Allies. Oxford: Oxford University Press; 2001

21. Erritzøe J, Mann CF, Brammer F, Fuller RA. Cuckoos of the world. London: Christopher Helm; 2012.

22. Åkesson S, Klaassen R, Holmgren J, Fox JW, Hedenström A. Migration routes and strategies in a highly aerial migrant, the Common Swift Apus apus, revealed by light-level geolocators. PLoS ONE. 2012;7:e41195. doi:10.1371/journal.pone.0041195.
23. Willemoes M, Strandberg R, Klaassen RHG, Tøttrup AP, Vardanis Y, Howey PW, Thorup K, Wikelski M, Alerstam T. Narrow-front loop migration in a population of the common cuckoo Cuculus canorus, as revealed by satellite telemetry. PLoS ONE. 2014;9:e83515. doi:10.1371/journal. pone.0083515.

24. Afanasyev V. A miniature daylight level and activity data recorder for tracking animals over long periods. Mem Natl Inst Polar Res. 2004;58:227-33.

25. Thaxter CB, Ross-Smith VH, Clark JA, Clark NA, Conway GJ, Marsh M, Leat EHK, Burton NHK. A trial of three harness attachment methods and their suitability for long-term use on Lesser Blackbacked Gulls and Great Skuas. Ring Migr. 2015;29:65-76. doi:10.1080/03078698.2014.995546.

26. Fox J. Geolocator manual v8. British Antarctic Survey. www.antarctica. ac.uk/engineering/geo_downloads/Geolocator_manual_v8.pdf; 2010.

27. Lisovski S, Hewson CM, Klaassen RHG, Korner-Nievergelt F, Kristensen MW, Hahn S. Geolocation by light: accuracy and precision affected by environmental factors. Methods Ecol Evol. 2012;3:603-12.

28. R Development Core Team. R: a language and environment for statistical computing. Vienna: R Foundation for Statistical Computing; 2011

29. Pinzon JE, Compton JT. A non-stationary 1981-2012 AVHRR NDVI 3g time series. Remote Sens. 2014;6:6929-60.

30. McKinnon EA, Fraser KC, Stutchbury BJM. New discoveries in landbird migration using geolocators, and a flight plan for the future. Auk. 2013;130:211-22.

31. Cleere N, Nurney D. A guide to the nightjars and related nightbirds. Robertsbridge: Pica Press; 1998.

32. Cresswell B, Edwards D. Geolocators reveal wintering areas of European Nightjar (Caprimulgus europaeus). Bird Study. 2013;60:77-86.

33. Norevik G, Åkesson S, Hedenström A. Migration strategies and annual space-use in an Afro-Palaearctic aerial insectivore-the European nightjar Caprimulqus europaeus. J Avian Biol. 2017. doi:10.1111/jav.01071.

34. King JR. Seasonal allocation of time and energy resources in birds. Publ Nuttall Ornithol Club. 1974:15:4-85.

35. Wingfield JC, Farner DS. Control of seasonal reproduction in temperatezone birds. Progr Reprod Biol. 1980;5:62-101.

36. Nilsson C, Klaassen RHG, Alerstam T. Difference in speed and duration of bird migration between spring and autumn. Am Nat. 2013;181:837-45.

37. Kranstauber B, Weinzierl R, Wikelski M, Safi K. Global aerial flyways allow efficient travelling. Ecol Lett. 2015;18:1338-45.

38. Sanderson FJ, Donald PF, Pain DJ, Burfield IJ, van Bommel FPJ. Longterm population declines in Afro-Palearctic migrant birds. Biol Conserv. 2006:131:93-105.

39. Wilcove DS, Wikelski M. Going, going, gone: is animal migration disappearing? PLOS Biol. 2008:6:1361-4

40. Vickery JA, Ewing SR, Smith KW, Pain DJ, Bairlein F, Skorpilov J, Gregory RD. The decline of Afro-Palaearctic migrants and an assessment of 583 potential causes. Ibis. 2014;156:1-22. doi:10.1111/ibi.12118.

41. Faaborg J, Holmes RT, Anders AD, Bildstein KL, Dugger KM, Gauthreaux SA, Heglund P, Hobson KA, Jahn AE, Johnson DH, Latta SC, Levey DJ, Marra PP, Merkord CL, Nol E, Rothstein SE, Sherry TW, Sillett S, Thompson FR, Warnock N. Conserving migratory land birds in the New World: do we know enough? Ecol Appl. 2007;20:398-418.

42. Runge CA, Martin TG, Possingham HP, Willis SG, Fuller RA. Conserving mobile species. Front Ecol Environ. 2014;12:395-402. doi:10.1890/130237.

43. Wilcove DS. No way home. Washington: Island Press; 2008.

44. Fair J, Paul E, Jones J, editors. Guidelines to the use of wild birds in research. Washington: Ornithological Council; 2010. 